\title{
The effect of the queen's age on the Varroa mite (Varroa destructor) burden of honey bee (Apis mellifera L.) colonies
}

\author{
${ }^{1}$ Marianna Takács - ${ }^{2}$ János Oláh \\ University of Debrecen \\ ${ }^{1}$ Faculty of Agricultural and Food Sciences and Environmental Management, \\ Department of Animal Science, Debrecen, Hungary \\ ${ }^{2}$ Farm and Regional Research Institute of Debrecen, Debrecen, Hungary \\ takacsmarianna@agr.unideb.hu
}

\begin{abstract}
SUMMARY
An apiary trial was conducted in 2016 August to October in Szabolcs-Szatmár-Bereg County, Nyírmada to evaluate the influence of queen's age on the Varroa destructor-burden in the treatment colonies. Sixty colonies of bees belonging to the subspecies Apis mellifera carnica pannonica in Hunor loading hives (with 10 frames in the brood chamber/deep super) were used. The colonies were treated with amitraz and the organophosphate pesticide coumaphos active ingredients. The amitraz treatment includes 6 weeks. The coumaphos treatment with Destructor $3.2 \%$ can be used for both diagnosis and treatment of Varroasis. For diagnosis, one treatment is sufficient. For control, two treatments at an interval of seven days are required. The colonies were grouped by the age of the queen: 20 colonies with one-year-old, 20 colonies with two-year-old and 20 colonies with three-year-old queen. The mite mortality of different groups was compared. The number of fallen mites was counted at the white bottom boards. The examination of spring growth of honey bee colonies has become necessary due to the judgement of efficiency of closing treatment. The data was recorded seven times between $16^{\text {th }}$ March 2017 and $19^{\text {th }}$ May 2017.

Data on fallen mites were subjected to one-way analysis of variance (ANOVA) and Post-Hoc Tukey-test. Statistical analysis was performed using the software of IBM SPSS (version 21.). During the first two weeks after treatments, the number of fallen mites was significantly higher in the older queen's colonies (Year 2014). The total mite mortality after amitraz treatment in the younger queen's colonies was lower $(P<0.05)$ compared to the three-year-old queen's colonies. According to Takács and Oláh (2016) although the mitemortality tendency, after the coumaphos (closing) treatment in colonies which have Year 2014 queen showed the highest rate, considering the mite-burden the colonies belongs to the average infected category. The colonial maintenance ability of three-year-old queen cannot be judged based on the influencing effect on the mite-burden. The importance of the replacement of the queen was judged by the combined effect of several factors.

During the spring-growth study $\left(16^{\text {th }}\right.$ March-19 ${ }^{\text {th }}$ May) was experienced in the three-year-old queen's colonies the number of brood frames significantly lower compared to the one-and two-year-old queen's colonies. In the study of $17^{\text {th }}$ April and $19^{\text {th }}$ May each of the three queen-year-groups were varied. Therefore in the beekeeping season at different times were determined the colonial maintenance ability of queens by more factors: efficiency of closing treatment in early spring, the spring-growth of bee colonies, the time of population shift (in current study, this time was identical in each queen-year), honey production (from black locust).
\end{abstract}

Keywords: queen's age, Varroa destructor, mite-burden, mite-mortality, coumaphos, amitraz

\section{INTRODUCTION}

The infamous Varroa destructor has become the most serious parasite of the European honey bees, causing a loss of millions of bee colonies (Stephen 2004). Beekeepers, crop growers, authorities, scientists and the general public are all concerned and alarmed with the mysterious die-offs of honey bee (Apis mellifera) colonies that have occurred during the last years in many countries around the world. Since 2006, disastrous colony losses have been reported in Europe and North-America. The causes of the losses were not readily apparent and have been attributed to overwintering mortalities (Conte et al. 2010). The phenomenon has been named Colony Collapse Disorder (Engelsdorp et al. 2008). Pathogens and other environmental stresses, including pesticides, have been linked to $\mathrm{CCD}$, but a causal relationship has not yet been demonstrated (Johnson et al. 2009). According to Neumann and Carreck (2010) the main cause of the Colony Collapse Disorder is the Varroa mite.

The ectoparasitic mite, Varroa destructor is a major pest of honey bees (Apis mellifera L.) worldwide (Sammantaro et al. 2000) that needs to be controlled because the untreated honey bee colonies within a few years due to damage to both pupae and adult bees (Elzen et al. 2000).

The Varroa destructor burden is depending on the population of bee colonies, which was influenced by the egg-laying rates of queen bees. In the Hungarian beekeeping practice the beekeeper experts change the queens, when they reach the age of two. The adoption of new queens has become difficult to implement because of the mixing of subspecies.

Unfortunately the Hungarian honey bee subspecies (Apis mellifera carnica pannonica) was contaminated by the introduction of alien subspecies, like honey bee from Italy, Apis mellifera ligustica (Kovács 2014), so it became necessary to determine how influence the queen's age the mite-burden and when is necessary change them.

Over the years, the laying ratio of queens could decrease depending on the age, therefore colonies headed by one-year-old queens have proved to be more efficient considering colony population and 
honey production than ones with older queens (Simeunovic et al. 2014), but the Varroa destructor burden was not demonstrated by the queen of different age during the researches of last years.

\section{MATERIAL AND METHODS}

\section{Apiary trial}

The trial was carried out in an apiary of sixty colonies of bees belonging to the subspecies Apis mellifera carnica pannonica, during summer and previous autumn of 2016 (August and September) and in the end of October in Szabolcs-Szatmár-Bereg county, Nyírmada, Hungary. The colonies were maintained in Hunor loading-hives. Altogether 60 colonies were observed in the experiment including 20 one-year-old, 20 two-year-old and 20 three-year-old queen bees. The aim of this work was to quantify the mite-mortality depending on the queen's age and furthermore determined the efficiency of the closing treatment based on the spring growth of treated honey bee colonies.

\section{The miticide preparations and follow-up of mite- mortality}

The treatments of 60 colonies in 2016 were performed by amitraz (6 weeks of treatment) and coumaphos (single treatment). Amitraz is a formamidine pesticide widely used in agriculture and veterinary medicine as an insecticide and acaricide (Leung et al. 1999). In the beekeeping, againts the Varroa destructor amitraz was used persistencemedicament. The persistence-medicament was Apivar, which made with amitraz (amidine) impregnated in plastic strips.

Coumaphos is an organophosphate insecticide, specially developed to target insects and mites (Kamrin 1997). The coumaphos in a different formulation has been used in Europe (Pettis 2004). The most popular chemical with coumaphos active ingredient which has been used by Hungarian beekeepers was the Destruktor $3.2 \%$ (as known to 2014 Perizin). The miticide preparation was distributed by Tolnagro Ltd.

The mite burden of colonies was judged depending on the influencing effect of queen-year.

In the treated colonies the plastic strips (dosage of amitraz, $500 \mathrm{mg}$ per strip) were inserted in the brood chamber of each hive and left for six weeks. During the treatment period the fallen mites were counted weekly using at white bottom boards.

During the coumaphos treatment the mite mortality was counted on the following day after both treatment.

The Destruktor $3.2 \%$ can be used for both diagnosis and treatment of Varroasis. For diagnosis one treatment is sufficient. For control, two treatments at an interval of seven days are required. Full sized colonies receive $50 \mathrm{ml}$ of the emulsion per treatment. Developing colonies receive half of this dose (25 $\mathrm{ml} /$ colony). The $10 \mathrm{ml}$ bottle of concentrate was diluted to $500 \mathrm{ml}$ using the bottom portion of the plastic applicator. The correct dose has been loaded into the dosing beaker it can be poured along all seams occupied by honey bees.

The Destruktor $3.2 \%$ concentrate was applied to clustering bees when there is no brood present. The Destructor $3.2 \%$ with coumaphos active ingredient is very effective against varroa mites on adult bees, but bee mortality occurred at low external temperatures (below $5{ }^{\circ} \mathrm{C}$ degrees).

\section{Spring-growth study}

The examination of spring growth of honey bee colonies has become necessary due to the judgments of efficiency of closing treatment

During the first spring control the number of brood frames data-recording was started on $16^{\text {th }}$ March. The study of the spring development of the colonies was carried out by monitoring the number of brood frames (Number of brood frames/Közép-Boczonádi brood chamber). From the 10 frames of brood chamber was recorded the number of frames with contiguous brood area for each hives. The spring-growth study was covered the examination of egg-laying rates of queen bees (18 colonies with three-year-old queen, 20 colonies with two-year-old queen, 20 colonies with one-year-old queen). The data was recorded seven times between $16^{\text {th }}$ March 2017 and $19^{\text {th }}$ May 2017.

\section{RESULTS}

Data on fallen mites and number of brood frames were subjected to one-way analysis of variance (ANOVA) and Post-Hoc Tukey-test. Statistical analysis was performed using the software of IBM SPSS (version 21.).

The average trends of fallen mites of 6 weeks amitraz treatment counted weekly at the white bottom boards of hives are reported in Table 1. During the first two weeks after amitraz treatments, the number of fallen mites was significantly higher in the older queen's colonies (Year 2014). In the last week of experiment this significant difference was also identical.

The total mite mortality after amitraz application in the younger queen's colonies was lower compared to the three-year-old queen's colonies despite of the larger population. Based on the Tukey-test between the Year 2015 and Year 2016 group was no statistically detectable difference, but the downward trend in the mite-mortality was well-marked.

The average trends of fallen mites of coumaphos (closing) treatment counted weekly at the white bottom boards of hives are reported in Table 2.

During the first treatment of the Destruktor 3.2\% miticide preparation (with coumaphos active ingredient) the number of fallen mites showed significant difference between the oldest queen's colonies and the youngest queen's colonies and this difference was typical between the Group 2015 and Group 2016. After the second treatment were experienced in the Year 2014 queen's colonies the mite mortality was significantly higher compared to the Year 2015 and 2016 queen's colonies. In case of the total number of fallen mites tendency was similar 
which was typical during the second treatment. Between the number of fallen mites of Year 2015 and
Year 2016 group was not statistically detectable difference.

Number of fallen mites during the six weeks of amitraz treatment

\begin{tabular}{|c|c|c|c|c|c|c|c|}
\hline \multirow{2}{*}{ Year of queen bee } & \multicolumn{7}{|c|}{ Means \pm SD } \\
\hline & $1^{\text {st }}$ week & $2^{\text {nd }}$ week & $3^{\text {rd }}$ week & $4^{\text {th }}$ week & $5^{\text {th }}$ week & $6^{\text {th }}$ week & Total \\
\hline 2014 & $50.2^{\mathrm{a}} \pm 3.1$ & $40.7^{\mathrm{a}} \pm 2.3$ & $30.4^{\mathrm{a}} \pm 2.7$ & $20.7^{\mathrm{a}} \pm 2.0$ & $19.4^{\mathrm{a}} \pm 1.6$ & $11.9^{\mathrm{a}} \pm 0.9$ & $173.2^{\mathrm{a}} \pm 8.9$ \\
\hline 2015 & $39.6^{\mathrm{b}} \pm 2.8$ & $33.1^{\mathrm{b}} \pm 2.0$ & $27.9^{\mathrm{a}} \pm 1.3$ & $26.4^{\mathrm{a}} \pm 2.0$ & $18.2^{\mathrm{a}} \pm 1.2$ & $8.9^{\mathrm{b}} \pm 1.0$ & $154.0^{\mathrm{b}} \pm 5.8$ \\
\hline 2016 & $37.5^{\mathrm{b}} \pm 2.5$ & $29.9^{\mathrm{b}} \pm 2.0$ & $26.8^{\mathrm{a}} \pm 2.1$ & $20.1^{\mathrm{a}} \pm 1.7$ & $15.2^{\mathrm{a}} \pm 1.4$ & $6.6^{\mathrm{b}} \pm 0.9$ & $136.0^{\mathrm{b}} \pm 6.4$ \\
\hline
\end{tabular}

Table 2

Number of fallen mites during the coumaphos treatment

\begin{tabular}{lccc}
\hline \multirow{2}{*}{ Year of queen bee } & \multicolumn{3}{c}{ Means \pm SD } \\
\cline { 2 - 4 } & $1^{\text {st }}$ treatment & $2^{\text {nd }}$ treatment & Total \\
\hline 2014 & $20.1^{\mathrm{a}} \pm 1.2$ & $10.3^{\mathrm{a}} \pm 1.0$ & $31.4^{\mathrm{a}} \pm 2.0$ \\
2015 & $14.2^{\mathrm{b}} \pm 0.8$ & $6.4^{\mathrm{b}} \pm 0.8$ & $20.6^{\mathrm{b}} \pm 1.5$ \\
2016 & $10.1^{\mathrm{c}} \pm 0.6$ & $4.7^{\mathrm{b}} \pm 0.5$ & $14.7^{\mathrm{b}} \pm 0.9$ \\
\hline
\end{tabular}

Note: ${ }^{\text {a-c }}$ group means with similar letters are not significantly different at 0.05 level (According to One-way analysis of variance); Source: IBM SPSS (Version 21.)

The average trends of brood frames are reported in Table 3. During the evaluating our results we experienced that in the colonies with the queen of the year 2014 the number of brood frames showed a significant difference between colonies with one and two-year-old queen's colonies. In the colonies with the oldest queen bees were detected an average of 1.9 brood frames in each brood chamber, while in the colonies with one and two-year-old queen bees were found an average 2.7 brood frames. There was no significant difference between the queen of the year 2015 and 2016 on $29^{\text {th }}$ March and on $10^{\text {th }}$ April. In these bee colonies, on $1^{\text {st }}$ May, there was a large-scale brood area in 6-7 frames, while in the three-year-old queen' s colonies, this condition was detected on May $19^{\text {th }}$. In the study of $17^{\text {th }}$ April and $19^{\text {th }}$ May each of the three queen-year-group were varied. In $17^{\text {th }}$ April a population shift was experienced in the honey bee colonies.

Number of brood frames during the spring-growth study

\begin{tabular}{lccccccc}
\hline \multirow{2}{*}{ Year of queen bee } & \multicolumn{5}{c}{ Means \pm SD } \\
\cline { 2 - 7 } & $16^{\text {th }}$ March & $29^{\text {th }}$ March & $10^{\text {th }}$ April & $17^{\text {th }}$ April & $1^{\text {st }}$ May & $11^{\text {th }}$ May & $19^{\text {th }}$ May \\
\hline 2014 & $1.9^{\mathrm{a}} \pm 0.7$ & $2.0^{\mathrm{a}} \pm 0.8$ & $2.5^{\mathrm{a}} \pm 0.7$ & $3.6^{\mathrm{a}} \pm 0.5$ & $4.5^{\mathrm{a}} \pm 0.6$ & $5.4^{\mathrm{a}} \pm 0.6$ & $6.5^{\mathrm{a}} \pm 0.6$ \\
2015 & $2.7^{\mathrm{b}} \pm 0.5$ & $3.5^{\mathrm{b}} \pm 0.5$ & $4.2^{\mathrm{b}} \pm 0.5$ & $5.4^{\mathrm{b}} \pm 0.8$ & $6.9^{\mathrm{b}} \pm 0.7$ & $7.7^{\mathrm{b}} \pm 0,6$ & $8.4^{\mathrm{b}} \pm 0.7$ \\
2016 & $2.7^{\mathrm{b}} \pm 0.6$ & $3.9^{\mathrm{b}} \pm 0.9$ & $4.6^{\mathrm{b}} \pm 0.8$ & $6.2^{\mathrm{c}} \pm 0.7$ & $7.2^{\mathrm{b}} \pm 1.0$ & $8.2^{\mathrm{b}} \pm 0.9$ & $9.0^{\mathrm{c}} \pm 0.8$ \\
\hline
\end{tabular}

Note: ${ }^{\text {a-c }}$ group means with similar letters are not significantly different at 0.05 level (According to One-way analysis of variance); Source: IBM SPSS (Version 21.)

\section{CONCLUSIONS}

During the six weeks of amitraz-treatment the third to fifth weeks the queen-year effect on the miteburden did not cause significant difference, the explanation of which lies in this time downward trend of brood by the queens in the hives.

In practical aspects of our results we confirmed that in colonies with younger queen, despite of the bigger population, the mite-burden was significantly lower compared to the colonies with older queens (2014).

In the young queen's colonies the influencing effect of queen on the mite-burden showed in that in these colonies the spread of emitted amitraz by the persistance-medicament in plastic strips within the hives was realized by the bigger population.

Younger queens have a greater egg laying potential and they produce a greater proportion of uninfected newly enclosed bees to compensate for adult bee losses (Botias et al. 2012).

The coumaphos treatment was the closing treatment in the beekeeping season of 2016. Closing treatment is the most effective defense during the year, because the whole mite-population exposed to the effect of miticide preparation (brood-free period) (Nagy 2015) 
Based on Randy (2007) the acceptable economic threshold (ET) should be laid down. Different threshold was published to different seasons of the beekeeping and different geographic locations.

The economic threshold (ET) of Varroa destructor was in autumn 59-187 (Delaplane and Hood 1999) and 50 (Currie and Gatein 2006).

During the six weeks treatment and closing treatment we experienced only in the first part of closing treatment significant difference between each of the three queen-years.

According to Takács and Oláh (2016) although the mite-mortality tendency, after the coumaphos (closing) treatment in the colonies which have threeyear-old queen showed the highest rate, considering the mite-burden, the colonies belong to the average infected category (Table 4). The strongly infected or critically infected categories was not reached by the colonies, the overwinter of colonies was become secure by the reduction-handling of the mitepopulation in the old queen's colonies too. The categorization of colonies was not feasible by the number of fallen mites during the six-week treatment, therefore these category suitable to determine the conditions of closing treatment.

Mite infection categories

\begin{tabular}{lc}
\hline \multicolumn{1}{c}{ Category } & Number of fallen mites \\
\hline Moderately infected & $0-20$ \\
Average infected & $21-50$ \\
Strongly infected & $51-75$ \\
Critically infected & Above 75 \\
\hline
\end{tabular}

Source: Takács and Oláh (2016)

The behavior of bees against the mite is largely dependent on the queen bee. Two related behaviors, hygienic behavior (HB) and Varroa sensitive hygiene (VSH), are highly variable among A. mellifera colonies (Parker et al. 2012). When in the colonies phenomenon of the hygienic behavior and VSH decreases, subservient to examine the health status of queens by the brood-area of frames in early spring.
During the first early-spring control was evaluated the efficiency of the closing treatment. The proper time and type of spring-treatment was determined by the efficiency of closing treatment and in this period the effect of queen-age was examined by more factors: egg-laying rates and varroa-burden.

The colonial maintenance ability of older queen we cannot judge based on the influencing effect on the mite-burden. The importance of the replacement of the queen was judged by the combined effect of several factors.

In 2016 there was no significant difference between the number of fallen mites of one-year-old and two-year-old queen's colonies, but the mitemortality of three-year-old queen's colonies was significantly higher, so we concluded the vitality and the health of honey bees were influenced by the age of queens. But this influencing factor is not enough to determine in proper time the colonial maintenance ability of the queen.

During the spring-growth study was experienced in the three-year-old queen's colonies the number of brood frames significantly lower compared to the oneand two-year-old queen's colonies. This trend was also typical on the mite-burden tendency in each year. However at the time of population shift all three queen-year were different. This significant difference was detected on $19^{\text {th }}$ May, when the honey collection from black locust influenced the egg-laying rates of queen bees.

Therefore in the beekeeping season at different times was determined the colonial maintenance ability of queens by more factors: efficiency of closing treatment in early spring, the spring-growth of bee colonies, spring incentive (sugar-pie, 1:1 sugar syrup), the time of population shift (in current study, this time was identical in each queen-year), honey production (from black locust).

\section{ACKNOWLEDGEMENTS}

The publication is supported by the EFOP-3.6.3VEKOP-16-2017-00008 project. The project is cofinanced by the European Union and the European Social Fund.

\section{REFERENCES}

Botias, C.-Hernández, R.-Días, M. J.-Garcia-Palencia, P.Matabuena, M.-Juarranz, A.-Barrios, L.-Meana, A.-Nanetti, A.-Higes, M. (2012): The effect of induced queen replacement on Nosema spp. infection in honey bee (Apis mellifera iberiensis) colonies. Environmental Microbiology. 14: 845859.

Conte, Y. L.-Ellis, M.-Ritter, W. (2010): Varroa mites and honey bee health: can Varroa explain part of the colony losses? Apidologie. 41: 353-363.

Currie, R. W.-Gatein, P. (2006): Timing acaricide treatments to prevent Varroa destructor from causing economic damage to honey bee colonies. 138. 2: 238-252.
Delaplane, K. S.-Hood, W. M. (1999): Economic threshold for Varroa jacobsoni Oud. in the southeastern USA. Apidologie. 30. 5: 383-395.

Elzen, P. J.-Baxter, J. R.-Spivak, M.-Wilson, W. T. (2000): Control of Varroa jacobsoni Oud. resistant to fluvalinate and amitraz using coumaphos. Apidologie. 31: 437-444.

Engelsdorp, van D.-Hayes, J.-Underwood, R. M.-Pettis, J. (2008): A survey of honey bee colony losses in the U.S., fall 2007 to spring 2008. PloS ONE. 3: 1-6.

Johnson, R. M.-Evans, J. D.-Robinson, G. E.-Berenbaum, M. R. (2009): Changes in transcript abundant cerelating to Colony Collapse Disorder in honey bees (Apis mellifera). PNAS. 106: 35 . 
Kamrin, M. A. (1997): Pesticide Profiles: Toxicity, Environmental Impact, and Fate CRC Press. [In: Schweikert and Burritt (2012): The organophosphate insecticide Coumaphos induces oxidative stress and increases antioxidant and detoxification defences in the green macroalgae Ulva pertusa.] Aquatic Toxocology. 122-123: 86-92.

Kovács, L. (2014): Bee-breeding in Hungary. Méhészet. 62. 4: 1011.

Leung, V. K. S.-Chan, T. Y. K.-Yeung, V. T. F. (1999): Clinical Toxicology. Journal of Toxicology. 37: 513-514.

Nagy Cs. (2015): A zárókezelés ideje. Méhészújság. Az Országos Magyar Méhészeti Egyesület lapja. 2015. 11. 07.

Neumann, P.-Carreck N. L. (2010): Honey bee colonies losses. Journal of Apicultural Research. 49. 1: 1-6.

Parker, R.-Guarna M. M.-Melathopoulos A. P.-Moon K. M.White R.-Huxter E.-Pernal S. F.-Foster L. J. (2012): Correlation of proteome-wide changes with social immunity behaviours provides insight into resistance to the parasitic mite, Varroa destructor, in the honey bee (Apis mellifera). Genome Biology. 12: 66-81.
Pettis, J. S. (2004): A scientific note on Varroa destructor resistance to coumaphos in the United States. Apidologie. 35: 91-92.

Randy, O. (2007): Scientific Beekeeping. http:// scientificbeekeeping.com/tag/nosema-cereanae/

Sammantaro, D.-Gerson, U.-Needham, G. (2000): Parasitic mites of honey bees: life history, implications and impact. Ann. Rev. Entomol. 45: 519-548.

Simeunovic, P.-Stevanovic, J.-Cirkovic, D.-Rodojicic, S.-Lakic, N.-Stanisic, L.-Staminimirovic, Z. (2014): Nosema cerenae and queen age influence the reproduction and productivity of the honey bee colony. Journal of Apicultural Research. 53. 5: 545-554.

Stephen, J. M. (2004): Acaricide (pyrethroid) resistance in Varroa destructor. Bee World. 85: 67-69.

Takács M.-Oláh J. (2016): A Varroa destructor elleni védekezés problémakörének elemzése. [In: Keresztes G. (szerk.) TAVASZI SZÉL: Tanulmánykötet - I. kötet.] Doktoranduszok Országos Szövetsége. Budapest. 147-155. 